
ISSN : 2615-1995, E-ISSN : 2615-0654

J. Madani., Vol. 2, No. 1, Maret 2019 (131 - 144)

(C)2018 Lembaga Kajian Demokrasi

MADANI

dan Pemberdayaan Masyarakat (LKD-PM)

\title{
STRATEGI PENGEMBANGAN JAMU KEMASAN DI INDONESIA
}

\author{
Hendra Winarsa \\ Fakultas Ekonomi, Universitas Pamulang \\ winarsahendra@gmail.com
}

\begin{abstract}
Abstrak
Penelitian ini bertujuan untuk mengetahui jenis jamu kemasan yang dikonsumsi konsumen di Indonesia, bentuk jamu kemasan yang disukai konsumen, faktor-faktor apa saja yang mempengaruhi konsumen membeli jamu kemasan, loyalitas konsumen jamu kemasan dan daya saing jamu kemasan terhadap produk lainnya, seperti obat medis dan jamu impor. Metode penelitian ini menggunakan metode penelitian korelasional yang menghubungkan dua variable atau lebih, bersifat kuantitatif dengan metode studi kasus pada industri jamu kemasan di Indonesia. Data yang digunakan dalam penelitian ini terdiri dari dua jenis yaitu data primer dan data sekunder. Metode analisis dalam penelitian ini menggunakan Uji Validitas, Uji Reabilitas, Regresi sederhana, Uji korelasi dan Uji T-test (Paired T-Test). Kesimpulan dari hasil penelitian adalah: 1. Jenis jamu kemasan yang dikonsumsi oleh konsumen adalah produk jamu kemasan yang khasiatnya tidak ada di dalam produk obat medis. 2. Bentuk Jamu kemasan yang disukai konsumen adalah berbentuk cair dan pil/ tablet. 3. Keunggulan jamu kemasan pada kandungan alami di produk jamu kemasan, kualitas produk yang bagus, kemudahan mendapatkan produk dan harga yang terjangkau. 4. Daya saing produk jamu kemasan dibandingkan dengan produk obat medis kurang baik, sedangkan dibandinkan dengan jamu impor lelatif lebih baik. 5. Belum tingginya loyalitas pengguna terhadap jamu kemasan. Sebagian besar pengguna masih menempatkan jamu sebagai alternative. Hasil penelitian ini menyarankan beberapa hal, antara lain : 1. Produsen jamu kemasan memfokuskan produknya pada jenis jamu yang tidak terdapat di produk obat medis dan produk yang berkaitan dengan perawatan tubuh dan kecantikan. 2. Bentuk produk difokuskan ke bentuk yang praktis, seperti bentuk cair, pil/tablet. 3. Informasi pada produk jamu kemasan diperjelas, seperti khasiat, komposisi jamu, dan aturan pakai.
\end{abstract}

Kata Kunci : Jamu Kemasan, Persaingan, Loyalitas, Pengembangan Produk.

\begin{abstract}
This research aims to know the types of herbal packaging consumed consumers in Indonesia, the shape of the packaging of herbs preferred consumer, factors that influence what consumers buy, herbal packaging and consumer loyalty resources pavkaging herbs against competitive products, such as medical and herbal imports. This research method using research methods korelasional that connects two or more variables, quantitative methods are case studies on herbal packaging industry in Indonesia. The data used in this study are of two types i.e., primary data and secondary data. Methods of analysis in this study uses the Validity Test, test Reabilitas, simple Regression, correlation and T-test-test-test (Paired T-Test). The conclusion of the results of the research are: 1. Types of herbal packaging consumed by consumers is the product packaging that herbal which is not in medical drug products. 2. Form of Herbs preferred packaging consumers are shaped liquid and pills/tablets 3. Advantages of herbal packaging in natural deposits in herbal products packaging, good quality products, convenience products and reasonable prices. 4. The packaging of herbal products competitiveness compared with less good medical drug products, and more good with importing herbal . 5. Customer loyalty of Indonesia herbis not hight.Most users are still putting the herbs as an alternative. The results of this study suggest several things, among others: 1. The manufacturer of the packaging products focusing on herbal medicine types of herbal medicine which is not found in medical drug products and products related to beauty and body treatments. 2 . Products focused to a practical form, such as the liquid form, pills/tablets. 3. information on medicinal products packaging made clear, such as efficacy, the composition of the herbs and the rules of use.
\end{abstract}


Keywords : Indonesia Herbal Packaging, Competition, Loyalit, Product Development.

\section{PENDAHULUAN}

\section{Latar Belakang}

Indonesia adalah negara yang sangat kaya akan tumbuhan obat. Beberapa sumber menyebutkan terdapat sekitar 30 ribu jenis tanaman obat. Dari jumlah sebanyak itu, yang sudah dimanfaatkan dan diketahui manfaatnya baru ratusan jumlahnya. Hal ini berarti masih sangat banyak tanaman obat yang belum dimanfaatkan. Secara tradisional, tanaman obat ini digunakan untuk pembuatan jamu (Anonim, 2007). Jamu merupakan warisan budaya bangsa yang sudah digunakan secara turun menurun. Indonesia memiliki keunggulan dalam hal pengembangan jamu dengan 9.600 jenis tanaman obat yang dapat digunakan sebagai bahan dasar jamu. Dengan seiringnya perkembangan jaman yang telah mengangkat kembali slogan back to nature, jamu kembali mendapatkan perhatian bagi pemerhati kesehatan di Indonesia.Dari sisi dunia kesehatan, kalau dulu masyarakat lebih fokus pada proses penyembuhan penyakit yang cepat, kini pandangan masyarakat telah bergeser ke proses pemeliharaan kesehatan dan pencegahan penyakit. Sama hanya dengan obat-obatan. Kalau dulu orang tidak peduli dari mana suatu obat berasal, yang penting sembuh. Sekarang asal muasal obat juga menjadi faktor penting dalam menentukan obat yang akan dikonsumsi. Obat tradisional dianggap memiliki resiko efek samping rendah daripada obat sintetis.

Dari sisi perekonomian, industri jamu telah berkontribusi sangat besar bagi pendapatan nasional, peningkatan kesejahteraan masyarakat dan penyediaan lapangan kerja. Bahan baku hampir mencapai sekitar 99\% yang digunakan merupakan produk dalam negeri dinilai mampu membawa multiplier effect yang cukup signifikan dalam pertumbuhan perekonomian di Indonesia mulai dari sektor hulu (pertanian) hingga sektor hilir yang meliputi perindustrian dan perdagangan. Perkembangan industri jamu di Indonesia dalam lima tahun terakhir menunjukkan pertumbuhan yang signifikan dengan pertumbuhan omzet yang baik. Jumlah industri jamu tercatat sebanyak 1.166 industri yang terdiri dari 129 industri besar dan 1.037 merupakan industri kecil. Dari 1.166 industri tersebut, 129 industri besar dan 621 industri kecil sudah tergabung dalam Gabungan Pengusaha Jamu (GP Jamu, 2004).

Dalam aktivitas ekonominya, pasar industri jamu Indonesia telah menunjukkan pertumbuhan yang signifikan dan daerah konsumen terbesar di Pulau Jawa mencapai 60\% pada tahun 2007 dan telah menciptakan tiga juta lapangan kerja (GP Jamu, 2008).

Sebagian besar produk nasional jamu diserap di dalam negeri dan hanya sebagian kecil untuk diekspor ke beberapa negara seperti Singapura dan Malaysia.

Faktor lain seperti perubahan tren gaya hidup juga mempengaruhi pola konsumsi jamu. Industri farmasi juga melihat peluang tersebut, sehingga beberapa industri farmasi memasuki mencoba memasuki pasar jamu di Indonesia.

Jepang mempunyai warisan minum teh, Korea mempunyai budaya minum gingseng. Warisan budaya tersebut mereka rawat hingga saat ini. Karena jamu merupakan produk warisan budaya bangsa Indonesia, kita perlu menciptakan tradisi cinta terhadap produk asli Indonesia.

Perusahaan jamu juga mendapat tantangan untuk mengembangkan strategi khusus dalam peningkatan brand awareness masyarakat Indonesia terhadap produk jamu. Semua program yang dilakukan oleh pengusaha domestik, khususnya pengusaha jamu, tidak akan sukses tanpa dukungan dari masyarakat Indonesia dan Pemerintah. Tugas utama kita adalah melestarikan dan cinta produk warisan leluhur sebagai tradisi yang tidak dapat digoyahkan oleh berbagai isu dan permasalahan yang terjadi baik di dalam maupun luar negeri. Berdasarkan Keputusan Kepala BPOM tentang Ketentuan Pokok Pengelompokkan dan Penandaan Obat Bahan Alam Indonesia, ada pembagian kategori berdasarkan cara pembuatan, klaim penggunaan dan tingkat pembuktian khasiatnya, yakni Jamu, Obat Herbal Terstandar dan Fitofarmaka. Ketiganya kategori tersebut harus aman dan memenuhi persyaratan mutu yang berlaku.

\section{Jamu}

Klaim khasiat Jamu dibuktikan secara turuntemurun (empiris) namun tidak boleh mengklaim memberikan kesembuhan penyakit. Diproduksi secara sederhana dengan peralatan yang sederhana dan bahan bakunya belum terstandar. Contoh dari kategori ini antara lain jamu beras kencur, dan jamu gendong lainnya.

\section{Obat Herbal Terstandar}

Klaim khasiat dari obat herbal terstandar dibuktikan secara ilmiah yaitu melalui uji preklinik (menggunakan hewan coba), bahan bakunya telah distandardisasi dan diproduksi di fasilitas yang modern (CPOTB).

\section{Fitofarmaka}

Klaim khasiat dari fitofarmaka dibuktikan secara ilmiah yaitu melalui uji pre-klinik dan uji klinik (diuji coba ke manusia/sukarelawan), menggunakan bahan baku yang sudah terstan- 
dar dan dibuat dengan menggunakan fasilitas produksi yang memenuhi standar Cara Pembuatan Obat Tradisional yang Baik (CPOTB).

Oleh karena ketatnya persyaratan Fitofarmaka, maka Obat Bahan Alam kategori ini setara dengan obat sintetis modern lainnya, serta bisa diresepkan oleh dokter. Namun sayangnya, jumlah produk Fitofarmaka di Indonesia masih sangat sedikit.

Industri jamu Indonesia saat ini mengalami tantangan yang cukup berat. Tidak saja di dalam negeri, tapi dari luar negeri, terutama memasuki era perdagangan bebas ASEAN (AFTA) yang semakin membayang di pelupuk mata. Persaingan diperkirakan akan sangat ketat, terutama dengan negara kompetitor yang mampu memproduksi dengan harga lebih murah (Sinaga, 2002).

Dari luar negeri, persaingan datang dari negara kompetitor Cina dan Malaysia. Namun, tantangan berat datang dari negeri Cina yang lebih dahulu dikenal sebagai negara produsen jamu tertua di dunia. Harga jamu dari Cina yang lebih murah dibandingkan jamu dari Indonesia dipastikan mengancam kelangsungan industri jamu tradisional. Sementara tantangan dari dalam negeri sendiri adalah dari sikap dunia medis yang belum sepenuhnya menerima jamu dan obat tradisional. Merebaknya jamu palsu maupun jamu yang bercampur bahan kimia beberapa waktu lalu, semakin menambah keraguan masyarakat akan khasiat dan keamanan mengonsumsi jamu tradisional Indonesia.

Bagi sebagian masyarakat Indonesia, minum jamu memang sudah biasa. Tetapi tradisi minum jamu sekarang tidak mendarah daging lagi di kalangan masyarakat. Sekarang lifestyle berubah, masyarakat Indonesia lebih memilih makanan dan minuman yang tidak menyehatkan. Muncul satu kebiasaan kurang baik masyarakat Indonesia yang menyukai segala sesuatu yang serba "instan", yang sebenarnya dapat berdampak negatif bagi kesehatan.

Dari sudut pandang masyarakat, Persepsi mengenai jamu disinyalir sangat memprihatinkan. Banyak yang beranggapan jamu rasanya pahit, jamu untuk orang tua, bahkan jamu adalah minuman orang kampung.

Perusahaan jamu mendapatkan tantangan untuk mengembangkan strategi khusus dalam peningkatan brand awareness masyarakat Indonesia terhadap produk jamu. Semua program yang dilakukan oleh pengusaha domestik, khususnya pengusaha jamu, tidak akan sukses tanpa dukungan dari masyarakat Indonesia dan Pemerintah.

\section{Batasan Masalah}

Untuk menghindari agar permasalahan ti- dak meluas, maka diperlukan batasan-batasan masalah sesuai dengan tujuan penelitian yang hendak dicapai. Yang menjadi obyek penelitian adalah pengembangan Obat Herbal Terstandar dan Fitofarmaka. Kedua produk tersebut di masyarakat populer disebut jamu kemasan.

\section{Perumusan Masalah}

Informasi tentang perilaku konsumen masyarakat Indonesia terhadap jamu kemasan, faktor-faktor yang mempengaruhi konsumen membeli jamu kemasan dan daya saing jamu kemasan Indonesia belum jelas. Untuk tujuan itu, pertanyaan pada penelitian ini diformulasikan sebagai berikut.

1. Bagaimana perilaku masyarakat Indonesia terhadap konsumsi jamu kemasan?

2. Faktor apa yang mempengaruhi konsumen dalam proses pengambilan keputusan pembelian jamu kemasan?

3. Bagaimanakah daya saing jamu kemasan Indonesia?

4. Apa saja usulan yang dapat diajukan untuk meningkatkan potensi pasar jamu kemasan berdasarkan perilaku konsumen dalam proses pengambilan keputusan pembelian jamu?

\section{Kerangka Pemikiran}

Konsumen dalam mengkonsumsi jamu kemasan untuk pemenuhan kebutuhannya dipengaruhi oleh pihak eksternal yang meliputi pengaruh lingkungan dan budaya serta pengaruh internal yaitu konsumen sebagai individu, seperti motivasi untuk mengkonsumsi jamu, persepsi konsumen terhadap jamu, sikap konsumen dan psikologi konsumen. Ketiga hal tersebut akan membentuk perilaku konsumen dalam mengkonsumsi jamu guna pemenuhan kebutuhan.

Dalam pelaksanaannya, konsumen akan melakukan beberapa tindakan sebelum memutuskan pembelian. Tindakan tersebut meliputi pengenalan produk jamu dimana konsumen akan mencari beberapa produk jamu yang dinilai dapat menjadi pemuas kebutuhan. Jika produk sejenis telah diketahui, konsumen kemudian akan melakukan pencarian informasi secara lengkap untuk mendapatkan produk yang tepat sesuai dengan kebutuhannya.

Keputusan pembelian konsumen dapat diperkuat dan dipengaruhi oleh perilaku produsen dalam menjual produknya ke konsumen. Usaha produsen, dalam hal ini jamu kemasan, seperti penentuan harga yang kompetitif dan terjangkau bagi konsumen, kemudahan memperoleh produk melalui distribusi yang tepat, promosi yang menarik dalam menyampaikan pesan produk, serta produk yang berkualitas dalam pemenuhan kebutuhan konsumen merupakan aspek yang berpengaruh. 


\section{Kajian Teoritis \\ Keputusan Pembelian \\ Konsumen Terhadap Suatu Produk}

Menurut Kotler (2002), keputusan pembelian adalah tindakan dari konsumen untuk mau membeli atau tidak terhadap produk. Dari berbagai faktor yang mempengaruhi konsumen dalam melakukan pembelian suatu produk atau jasa, biasanya konsumen selalu mempertimbangkan kualitas, harga dan produk yang sudah dikenal oleh masyarakat.

Sebelum konsumen memutuskan untuk membeli, biasanya konsumen melalui beberapa tahap terlebih dahulu yaitu, (1) pengenalan masalah, (2) pencarian informasi. (3) evaluasi alternatif, (4) keputusan membeli atau tidak, (5) perilaku pasca pembelian. Pengertian lain tentang Keputusan pembelian menurut Schiffman dan Kanuk (2000: 437) adalah "the selection of an option from two alternative choice". Dapat diartikan, keputusan pembelian adalah suatu keputusan seseorang dimana dia memilih salah satu dari beberapa alternatif pilihan yang ada.

Berdasarkan definisi di atas disimpulkan bahwa keputusan pembelian adalah tindakan yang dilakukan konsumen untuk melakukan pembelian sebuah produk. Oleh karena itu, pengambilan keputusan pembelian konsumen merupakan suatu proses pemilihan salah satu dari beberapa alternatif penyelesaian masalah dengan tindak lanjut yang nyata. Setelah itu konsumen dapat melakukan evaluasi pilihan dan kemudian dapat menentukan sikap yang akan diambil selanjutnya.

\section{Peranan Konsumen}

\section{Dalam Keputusan Pembelian}

Menurut Swastha dan Handoko (2011) berpendapat bahwa lima peran individu dalam sebuah keputusan membeli, yaitu:

1. Pengambilan inisiatif (initiator): individu yang mempunyai inisiatif pembelian barang tertentu atau yang mempunyai kebutuhan atau keinginan tetapi tidak mempunyai wewenang untuk melakukan sendiri.

2. Orang yang mempengaruhi (influencer): individu yang mempengaruhi keputusan untuk membeli baik secara sengaja maupun tidak sengaja.

3. Pembuat keputusan (decider): individu yang memutuskan apakah akan membeli atau tidak, apa yang akan dibeli, bagaimana membelinya, kapan dan dimana membelinya.

4. Pembeli (buyer): individu yang melakukan pembelian yang sebenarnya.

5. Pemakai (user): individu yang menikmati atau memakai produk atau jasa yang dibeli. Sebuah perusahaan perlu mengenal peranan tersebut karena semua peranan mengandung implikasi guna merancang produk, menentukan pesan dan mengalokasikan biaya anggaran promosi serta membuat program pemasaran

\section{Diferensiasi Produk}

Pengertian diferensiasi produk secara umum merupakan pembedaan suatu produk dengan produk lainnya. Pengertian lain juga tentang diferensiasi produk adalah pembedaan suatu produk dalam suatu perusahaan, agar pihak konsumen dapat memilih produk yang mana, yang mereka inginkan. Yang menjadi alternatif konsumen untuk memilih suatu produk didasari pada warna, kualitas dan harga. Diferensiasi produk atau pembedaan produk merupakan suatu strategi perusahaan untuk mempromosikan produk yang diproduksinya dengan produk perusahaan pesaingnya. Strategi ini didayagunakan sehingga perusahaan dapat menghindari persaingan harga. Perusahaan meletakkan perbedaan dalam desain produk, merek, kemasan, ukuran dan rasa.

\section{Desain produk}

Desain produk adalah salah satu aspek pembentuk citra produk seperti warna, kualitas jaminan dan pertanggung jawaban.

\section{Merek}

Merek merupakan nama istilah simbol atau desain khusus atau beberapa kombinasi unsurunsur yang direncanakan untuk mengidentifikasi barang dan jasa.

\section{Kemasan}

Sebagai seluruh kegunaan merancang, memproduksi bungkus atas kemasan suatu produk. Diferensiasi memungkinkan perusahaan memperoleh keuntungan berdasarkan nilai tambah yang dirasakan dan diberikan kepada pelanggan.

Kotler (2002:2) secara garis besar menyatakan diferensiasi produk adalah penawaran produk perusahaan yang memiliki sesuatu yang lebih baik, lebih cepat dan lebih murah yang akan menciptakan nilai yang lebih tinggi bagi pelanggan dibandingkan produk pesaing.

Menurut Kotler (2002:328), diferensiasi adalah tindakan merancang serangkaian perbedaan yang berarti untuk membedakan tawaran perusahaan dengan tawaran pesaing. Selanjutnya Kotler (2002:329) menyebutkan bahwa perusahaan dapat mendiferensiasikan tawaran pasarnya menurut 5 dimensi, yaitu: produk, pelayanan, personalia, saluran pemasaran atau citra. Produk-produk fisik itu bervariasi dalam potensinya untuk diferensiasi. Di sini penjual menghadapi banyak sekali parameter rancangan yang mencakup bentuk, keistimewaan (feature), 
kinerja, kesesuaian, daya tahan, keandalan, kemudahan untuk diperbaiki, gaya dan rancangan.

Diferensiasi pelayanan meliputi kemudahan pemasanan, pengiriman pemasangan, pelatihan pelanggan, konsultasi pelanggan, pemeliharaan dan perbaikan dan keramahan.

Diferensiasi personalia meliputi : kemampuan, kesopanan, dapat dipercaya dapat diandalkan, cepat tanggap dan komunikasi.

Diferensiasi saluran meliputi: cakupan, keahlian, dan kinerja. Diferensiasi citra meliputi: cakupan, keahlian dan kinerja. Diferensiasi citra meliputi: Lambang, media, atmosfir dan citra.

Kotler (1999 : 364) mengemukakan suatu perbedaan atau diferensiasi dapat dikembangkan jika memenuhi syarat-syarat sebagai berikut :

1. Penting: Perbedaan itu memberikan banyak manfaat bagi cukup banyak pelanggan

2. Jelas: Perbedaan itu tidak dimiliki orang lain atau dapat dikemas dengan lebih jelas.

3. Unggul: Perbedaan itu lebih baik dari cara lain untuk mendapatkan manfaat yang sama.

4. Dapat dikomunikasikan: perbedaan itu dapat dimengerti dan di lihat oleh pembeli.

5. Mendahului: perbedaan itu tidak mudah ditiru pesaing

6. Terjangkau: pembeli dapat menjangkau selisih harganya

7. Menguntungkan: perusahaan memperoleh laba dengan menonjolkan perbedaan itu

Mc Carty dan Perreault mendefinisikan diferensiasi produk adalah penawaran produk perusahaan yang memiliki sewaktu yang lebih baik, lebih baru, lebih cepat dan lebih murah yang akan menciptakan nilai yang lebih tinggi bagi pelanggan produk pesaing (A.W. Tunggal, 2001 : 37)

Kemudian menurut Berkowits dan kawan kawan : "Differentiation is using innovation and significant point of difference in product offering higher quality, advance technology or superior service in a wide range of market segments". Artinya diferensiasi dilakukan dengan menggunakan inovasi dan bal hal yang berarti dari pembeda produk yang ditawarkan mencakup kualitas terbaik kemajuan teknologi atau pelayanan prima terhadap keseluruhan pasar Sasaran, (A.W. Tunggal, 2001: 37). Selanjutnya, dia mengatakan bahwa diferensiasi dapat didasarkan pada:

a. Physical differences misalnya: facture, kinerja, daya tahan, desain gaya, dan lain lain

b. Availability differences misalnya: Ketersediaan di toko, dapat dipesan lewat fax, telepon dan internet.

c. Service differences misalnya: memberikan pelayanan yang lebih baik terhadap konsumen.

d. Price differences: harga yang tinggi, harga menengah, harga rendah.

e. Image Differences misalnya: Symbol, Events,
Atmosfir, media.

Kesamaan produk biasanya ada di antara para pesaing dan diferensiasi bertujuan untuk mengembangkan kemampuan kemampuan khusus yang dipandang unik oleh seluruh industri dalam istilah pemasaran ini dikenal dengan pemasaran yang berbeda (differentiated marketing).

Selanjutnya dijelaskan oleh (Kotler 2002 : 329 : 332) bahwa banyak produk dapat didiferensiasi berdasarkan bentuk, ukuran, model atau struktur fisik sebuah produk. Keistimewaan yakni karakteristik yang melengkapi fungsi dasar produk. Mutu kinerja mengacu pada level di mana karakteristik dasar produk itu beroperasi. Kualitas kesesuaian adalah tingkat di mana semua unit yang di produksi adalah identik dan memenuhi spesifikasi sasaran yang dijanjikan. Daya tahan adalah suatu ukuran usia operasi produk yang diharapkan dalam kondisi normal dan atau berat. Keandalan adalah ukuran kemungkinan suatu produk tidak akan rusak atau gagal dalam suatu periode waktu tertentu. Mudah diperbaiki adalah suatu ukuran kemudahan untuk memperbaiki suatu produk yang rusak atau gagal. Gaya menggambarkan penampilan dan perasaan yang ditimbulkan oleh produk itu bagi pembeli. Rancangan adalah totalitas keistimewaan yang mempengaruhi penampilan dan fungsi suatu produk dari segi kebutuhan pelanggan.

Adapun manfaat dari diferensiasi produk yaitu :

1. Untuk melakukan modifikasi yang substansi terhadap produk yang dihasilkan selama ini.

2. Menciptakan produk baru untuk memberikan manfaat tanpa mengubah saluran distribusi pemasaran.

3. Memperpanjang daya guna produk yang dihasilkan sekarang.

4. Menarik keuntungan dari reputasi perusahaan karena produk yang dihasilkan, diminati oleh para pelanggan.

Sumandy (Copyright 2005) mengadakan penelitian tentang diferensiasi produk yang dilakukan oleh Pocari Sweat. Dia mengatakan bahwa diferensiasi merupakan hal yang penting. Namun menurutnya diferensiasi tidak boleh sekedar berbeda. Diferensiasi harus terlebih dahulu diuji pada konsumen apakah value yang ditawarkan itu dipersepsi penting atau tidak. Disinilah kehebatan Pocari Sweat, ia merupakan true brand, bukan taste brand, yang mana ia konsisten dan tidak terbujuk mengeluarkan produk dalam berbagai rasa. Dia isotonic, yang dijual adalah khasiatnya sebagai minuman pengganti ion-ion tubuh yang hilang. Dengan kekhasan produknya dan secara konsisten mengiklankan produknya,sampai sekarang produk tersebut terus berkembang penjualannya. 
Di masyarakat kita, sering dijumpai penyakit masuk angin. Penyakit ini di dunia kedokteran belum jelas kategorinya sehingga obat medis khusus untuk penyakit masuk angin belum ada obat medisnya. Disisi lain, masyarakat juga tahu,jamu adalah salah satu cara untuk mengobatinya. Hal ini juga telah dimanfaatkan oleh beberapa industri jamu kemasan untuk memproduksi jamu untuk menyembuhkan sakit masuk angin, seperti jamu Tolak Angin dan lainnya.

Jamu juga dikenal masyarakat kita bermanfaat untuk menjaga kesehatan badan.Hal ini sudah diketahui oleh nenek moyang kita. Demikian juga dengan khasiat jamu yang lain, yaitu bermanfaat untuk merawat kecantikan. Beberapa keunggulan jamu tersebut bisa dipakai sebagai pembeda dari obat farmasi.

\section{Loyalitas Pelanggan}

Pelanggan diartikan sebagai seseorang yang terbiasa untuk membeli dari satu tempat (Griffin, 2005:31) yang bila seorang pelanggan merasa puas terhadap produk tersebut maka dapat memunculkan rasa loyalitas.

Loyalitas telah diartikan berulang kali oleh banyak peneliti, Griffin (2005:5) mendefinisikan Loyalitas sebagai suatu kondisi dari durasi waktu tertentu dan mensyaratkan bahwa tindakan pembelian terjadi tidak kurang dari dua kali, Shet \& Mittal dalam Tjiptono (2008:392) menuliskan bahwa Loyalitas pelanggan adalah komitmen pelanggan terhadap suatu merek, toko atau pemasok, berdasarkan sikap yang sangat positif dan tercermin dalam pembelian utama yang konsisten

Dari definisi-definisi ini dapat disimpulkan bahwa loyalitas pelanggan secara garis besar adalah tentang pembelian berulang dan komitmen sehingga dapat ditarik kesimpulan bahwa loyalitas pelanggan adalah suatu komitmen seseorang dalam melakukan pembelian produk yang berulang ditempat/merek yang sama tanpa memperdulikan kondisi dan usaha marketing tempat lain.

\section{Keuntungan Loyalitas Pelanggan}

Beberapa perusahaan biasanya memilih untuk mempertahankan loyalitas pelanggan dan menjaganya tetap kuat dibandingkan berusaha mencari pelanggan baru. Hal ini disebabkan karena untuk memperoleh suatu pelanggan baru membuat perusahaan mengeluarkan biaya 5 kali lebih besar dibanding biaya untuk menjaga loyalitas pelanggan yang telah ada (Kotler dan Keller, 2009:178). Dan juga karena imbalan dari loyalitas yang bersifat jangka panjang dan kumulatif dimana semakin lama loyalitas pelanggan, semakin besar laba yang diperoleh dari satu pelanggan ini.

\section{Siklus Pembelian}

Sebelum pembeli menjadi pelanggan yang loyal, konsumen akan melakukan proses pembelian terlebih dahulu. Setiap kali pelanggan membeli, dia bergerak melalui siklus pembelian. Siklus pembelian di bagi menjadi 5 langkah yaitu:

1. Kesadaran

Langkah ini merupakan langkah utama dalam membentuk loyalitas pelanggan. Dalam langkah ini perusahaan mulai membentuk "pangsa pikiran" bagi calon pelanggan bahwa produk atau jasa yang ditawarkan lebih unggul dari pesaing. Kesadaran dapat ditimbulkan dari pemasaran produk melalui iklan atau kegiatan promosi lainnya.

2. Pembelian Awal

Langkah ini merupakan langkah penting dalam memelihara loyalitas pelanggan. Pembelian pertama kali merupakan pembelian percobaan dimana perusahaan dapat menanamkan kesan positif atau negatif dari produk yang diberikan. Hal ini dapat dilihat dari cara transaksi atau lingkungan/tempat penjualan.

3. Evaluasi Pasca Pembelian

Pelanggan secara sadar atau tidak sadar akan mengevaluasi transaksi. Bila mereka merasa puas atau ketidakpuasannya tidak terlalu tinggi sampai dapat dijadikan dasar pertimbangan untuk beralih ke pesaing maka tahap langkah selanjutnya yaitu keputusan membeli kembali mungkin dapat dilakukan.

4. Keputusan Membeli Kembali

Keputusan untuk membeli kembali merupakan hal yang penting bagi loyalitas pelanggan. Tanpa adanya pembelian berulang maka tidak akan ada loyalitas. Motivasi membeli kembali berasal dari tingginya sikap positif yang ditunjukkan terhadap produk yang di beli sebelumnya. Seringkali pelanggan memutuskan untuk membeli kembali sebagai langkah alamiah karena telah memiliki ikatan emosional yang kuat dengan produk tertentu.

5. Pembelian Kembali

Untuk dapat dianggap loyal maka pelanggan harus terus membeli kembali dari perusahaan yang sama dan mengulang langkah 3 hingga lima secara berulang-ulang. Pelanggan yang loyal akan menolak pesaing dan membeli kembali dari perusahaan yang sama kapanpun produk itu dibutuhkan atau diinginkan.

\section{Jenis-Jenis Loyalitas}

Setelah mengetahui siklus pembelian pelanggan, pada langkah terakhir yaitu pembelian kembali biasanya rasa loyalitas sudah tumbuh pada 
diri pelanggan. Namun untuk berbagai alasan, beberapa pelanggan tidak mengembangkan loyalitasnya terhadap suatu produk yang digunakan. Menurut Griffin (2005:23) loyalitas pelanggan dapat dibagi menjadi 4, yaitu:

1. Tanpa Loyalitas

Pembeli yang telah membeli produk tidak memperdulikan dimana mereka membeli asal mereka mendapatkan apa yang mereka butuhkan. Mereka tidak memilihi ikatan emosional terhadap produk atau jasa yang mereka gunakan.

2. Loyalitas yang Lemah (Inertia Loyalty)

Pelanggan yang membeli produk karena kebiasaan. Biasanya jenis pembelian ini dilakukan karena mereka selalu menggunakan produk tersebut dan mereka merasakan tingkat kepuasan tertentu dengan perusahaan. Loyalitas ini umumnya terjadi pada produk yang sering dibeli.

3. Loyalitas Tersembunyi (Latent Loyalty)

Biasanya loyalitas ini terjadi karena faktor situasi dan bukan pengaruh sikap yang menentukan pembelian berulang dimana pelanggan tidak dapat melakukan pembelian karena adanya situasi tertentu yang menahan pembelian berulang tersebut.

4. Loyalitas Premium

Merupakan tingkat preferensi paling tinggi dari loyalitas dimana pelanggan bangga karena menemukan dan menggunakan produk tertentu sehingga mereka dengan senang membagikan pengetahuan mereka kepada rekan dan keluarga.

\section{Tahapan-Tahapan Loyalitas Pelanggan}

Loyalitas pelanggan tidak terbentuk hanya dalam satu atau dua hari. Dalam menumbuhkan rasa loyalitas para pelanggan akan melewati beberapa tahap yang tiap tahapnya memerlukan kebutuhan khusus. Pada tahap-tahap inilah perusahaan memiliki peluang besar untuk mengubah pembeli menjadi pelanggan yang loyal.

1. Suspect adalah orang yang yang mungkin membeli produk atau jasa perusahaan. Disebut suspect karena yakin mereka akan membeli tetapi belum mengetahui tentang perusahaan dan produk yang ditawarkan perusahaan.

2. Prospect adalah orang yang membutuhkan produk dan memiliki kemampuan membeli. Mereka mungkin telah mengetahui informasi tentang perusahaan dan prduk namun masih belum memutuskan untuk membeli.

3. First Time Customer adalah orang yang membeli produk untuk pertama kalinya dan masih dapat berpaling dari produk perusahaan.

4. Repeat Customer adalah orang-orang yang telah membeli dari perusahaan sebanyak dua kali atau lebih. Mereka mungkin telah menggunakan dua jenis produk berbeda pada dua waktu yang berbeda.

5. Client adalah orang yang telah membeli produk secara teratur. Mereka akan membeli apapun yang perusahaan jual yang dapat dia gunakan. Client biasanya sudah memiliki tingkat loyalitas yang tinggi sehingga mereka tidak akan terpengaruh oleh daya tarik pesaing.

6. Advocate, sama seperti client, mereka membeli secara teratur apa yang perusahaan jual yang dapat mereka gunakan tapi mereka juga mendorong orang lain untuk membeli dari perusahaan. Advocate membantu promosi dan membawa pelanggan baru kedalam perusahaan.

\section{Hal yang Bisa dilakukan \\ Agar Konsumen Tetap Loyal}

Konsumen yang loyal akan mempermudah perusahaan ketika menyampaikan informasi terkait produk atau jasa-jasa terbaru. Biaya yang digunakan untuk membangun loyalitas konsumen lama juga lebih rendah dibanding mencari konsumen baru lagi.

Beberapa strategi yang bisa diterapkan untuk membangun kesetiaan atau loyalitas konsumen.

1. Memiliki Kelebihan Dibanding Pesaing Produk/jasa yang memiliki kelebihan dibanding pesaing cenderung lebih banyak dibeli. Kelebihan ini bisa dalam hal kualitas produk, ukuran (lebih besar), fitur (lebih lengkap), harga (lebih murah) ataupun hal lainnya misal rasa, kemasan. Hal-hal ini menjadi daya tarik tersendiri bagi konsumen supaya tidak beralih ke pesaing dan tetap setia membeli produk kita.

2. Wajib melakukan Inovasi

Jika Anda melakukan inovasi, secara tidak langsung akan membuat konsumen kita loyal. Kebutuhan konsumen selalu berubah dan cenderung ingin lebih, oleh sebab itu inovasi dan perbaikan produk perlu dilakukan terus menerus.

3. Ciptakan Varian Baru

Strategi yang dimaksud disini adalah kita wajib melakukan pengembangan produk melalui varian-varian baru. Banyak merekmerek besar yang berhasil mempertahankan pelanggan dikarenakan mereka membuat varian-varian baru. Misalnya saja produk shampo, ada shampo varian untuk anti ketombe, varian rambut lembut dan lain lain.

4. Membuat Program Promosi

Penerapan program promosi sangat diperlukan sebagai salah satu upaya kita memper- 
tahankan konsumen. Promosi diskon, paket produk, paket bundling serta paket dengan harga khusus menjadi salah satu strategi yang terbukti ampuh membangun loyalitas konsumen.

5. Bangun Komunikasi Dengan Konsumen

Kita wajib membangun komunikasi dengan konsumen. Hubungan kita dengan konsumen bila terjadi komunikasi terjalin secara rutin, maka konsumen akan tetap setia dan kecil kemungkinan untuk mencari produk lain.

\section{METODE \\ Sifat Penelitian}

Penelitian ini merupakan penelitian korelasional yang menghubungkan dua variable atau lebih,bersifat kuantitatif dengan metode studi kasus pada industri jamu kemasan di Indonesia. Merupakan data kuantitatif karena data-data yang digunakan berbentuk angka/numerik, dengan masalah yang sudah jelas dan populasinya luas.

\section{Jenis dan Sumber Data}

Data yang digunakan dalam penelitian ini terdiri dari dua jenis yaitu data primer dan data sekunder. Data primer merupakan data yang diperoleh langsung dari responden melalui kuesioner.

Data sekunder merupakan data yang diperoleh secara tidak langsung dan berfungsi sebagai data pendukung. Data sekunder diperoleh dari instansi terkait seperti Badan Pusat Statistik, Badan Pengawasan Obat dan Makanan (BPOM), Departemen Perdagangan, dan Gabungan Pengusaha Jamu (GP Jamu).

Data primer diambil di 10 daerah penelitian, antara lain Bandung, Semarang, Surabaya, Medan, Denpasar, Jakarta, Bogor, Depok, Tangerang (termasuk Tangerang Selatan), dan Bekasi. Pemilihan daerah responden berdasarkan kriteria tren konsumen jamu, kultur, dan keterwakilan daerah.

\section{Kerangka Pemikiran}

Kerangka pemikiran penelitian ini didasarkan pada model sederhana proses keputusan pembelian konsumen. Keputusan pembelian konsumen dapat diperkuat dan dipengaruhi oleh perilaku produsen dalam menjual produknya ke konsumen. Usaha produsen, dalam hal ini jamu, seperti penentuan harga yang kompetitif dan terjangkau bagi konsumen, kemudahan memperoleh produk melalui distribusi yang tepat, promosi yang menarik dalam menyampaikan pesan produk, serta produk yang berkualitas dalam pemenuhan kebutuhan konsumen merupakan aspek yang berpengaruh.

\section{Jenis Data, Sumber Data \\ dan Metode Pengumpulan Data}

Data yang digunakan dalam kajian ini terdiri dari dua jenis yaitu data primer dan data sekunder. Data primer merupakan data yang diperoleh langsung dari responden melalui survei dan wawancara kuesioner. Pertanyaan dalam kuesioner dapat berbentuk pertanyaan terbuka, pertanyaan tertutup, dan semi terbuka. Pertanyaan tertutup adalah pertanyaan yang telah memiliki jawaban sehingga responden tinggal memilih jawaban yang tersedia. Pertanyaan terbuka adalah pertanyaan yang dapat dijawab responden dengan cara yang hampir tidak terbatas karena tidak diberikan alternatif jawaban. Sedangkan pertanyaan semi terbuka adalah pertanyaan yang diberikan jawaban alternatif namun responden dapat mengisi jawaban selain alternaif jawaban yang telah disediakan.

Data sekunder merupakan data yang diperoleh secara tidak langsung dan berfungsi sebagai data pendukung. Data sekunder dalam kajian ini diperoleh dari instansi terkait seperti Badan Pusat Statistik, Badan Pengawasan Obat dan Makanan (BPOM), Departemen Perdagangan, dan Gabungan Pengusaha Jamu (GP Jamu).

a. Kuesioner

Data primer diambil di 10 daerah penelitian, antara lain Bandung, Semarang, Surabaya, Medan, Denpasar, Jakarta, Bogor, Depok, Tangerang, dan Bekasi. Pemilihan daerah responden berdasarkan kriteria tren konsumen jamu, kultur, dan keterwakilan daerah. Responden data primer masing-masing wilayah berjumlah 25 orang, sehingga total responden 250 orang, dengan menggunakan metode quota-purposive sampling. Kriteria konsumen adalah anggota masyarakat yang pernah mengkonsumsi jamu kemasan paling tidak sekali dalam 3 bulan terakhir. Sampel diambil secara kuota dengan variabel demografi jenis kelamin, tingkat pendidikan dan usia karena ditengarai bahwa respons masyarakat akan berbeda pada kelompok demografi ini Untuk mempermudah pendataan, wilayah Jakarta, Depok, Bogor, Tangerang, Bekasi kami gabung menjadi Jabodetabek.

b. Teknik Penentuan Skala

Menurut Malhotra, skala Linkert adalah pengukuran dengan lima kategori respon yang berkisar antara "sangat setuju" hingga "sangat tidak setuju”yang mengharuskan responden menentukan derajat persetujuan atau ketidaksetujuan terhadap masing-masing pertanyaan kuesioner.

c. Skala interval.

Menurut Istijanto(2009:83), skala interval adalah skala yang memiliki urutan dan me- 
miliki interval atau jarak yang sama antara kategori atau titik-titik terdekatnya.Untuk menentukan panjang kelas intervalnya, menurut Sudjana (2005:47), ditentukan dengan rumus : $\mathrm{P}$ (Panjang kelas) = Rentang Kelas/Banyak Kelas

\section{Metode Analasis Data}

Metode analisis dalam penelitian ini menggunakan Uji Validitas, Uji Reabilitas, Regresi sederhana,Uji korelasi dan Uji T-test (Paired T-Test).

\section{HASIL dan PEMBAHASAN}

Pada bab ini akan diuraikan hasil survei penelitian di daerah penelitian. Pada bagian pertama, akan diuraikan tentang konsumsi jamu kemasan. Pada bagian-bagian selanjutnya, diuraikan pula mengenai signifikansi atribut kesan kualitas, kesan kualitas mengenai jamu kemasan, kesadaran masyarakat terhadap jamu, asosiasi masyarakat mengenai jamu kemasan, serta loyalitas dan kepuasan konsumen terhadap jamu kemasan.

\section{Konsumsi Jamu}

\section{Jamu Kemasan yang diminum konsumen}

Tujuan dari penelitian ini adalah untuk mengetahui jenis jamu kemasan apa saja yang diminum oleh konsumen.

Dari hasil penelitian,secara nasional, 84\% responden telah meminum jamu tolak angin, 75\% jamu pegel linu, 58\% jamu kuat/sehat lelaki, 49\% jamu kewanitaan dan jamu perawatan kecantikan, $38 \%$ jamu pengobatan penyakit, dan 33\% jamu perawatan kesehatan. Dilihat dari data diatas, prosentase yang tinggi (diatas 50\%) didapat dari produk jamu kemasan yang fungsinya tidak dijumpai di dunia medis, seperti jamu tolak angin untuk menyembuhkan sakit masuk angin,jamu pegel linu dan lainnya. Dalam persepsi masyarakat, 'Masuk angin', sangat sering menjadi diagnosa mandiri masyarakat awam apabila tubuh kurang fit karena dirasa banyaknya 'angin' di dalam tubuh serta menimbulkan gejala seperti demam, keringat dingin, kembung, mual dan lainnya. Faktanya, medis tidak mengenal adanya istilah masuk angin. Adapun rangkaian gejala di atas biasanya mengarah ke 'flu like symptom' yang merupakan gejala awal timbulnya serangan virus. Dengan banyaknya masyarakat yang terkena masuk angin, di sisi lain belum ada obat medis, maka produk jamu untuk menyembuhkan masuk angin akan dicari masyarakat. Demikian juga dengan pegel linu, banyak ditemui di masyarakat, tetapi dari segi medis tidak didapat.

Sedangkan hasil yang kurang baik (dibawah $50 \%$ ) didapat dari produk jamu kemasan yang biasa dijumpai di dunia medis. Hal ini bisa dijelaskan bahwa obat untuk penyakit medis lebih dipercaya dari pada jamu. Memang, secara kualitas, pengujian obat farmasi lebih mendalam dari pada jamu

\section{Bentuk Jamu Kemasan yang Pernah Dikonsumsi}

Bentuk jamu yang dikonsumsi konsumen terbesar berbentuk jamu cair, dimana 51\% konsumen nasional meminum jamu jenis ini, diikuti oleh jamu serbuk (40\%) dan jamu kapsul atau pil (9\%).

\begin{tabular}{|c|c|c|c|c|c|c|c|}
\hline \multirow{2}{*}{$\begin{array}{c}\text { BENTUK } \\
\text { JAMUYANG } \\
\text { DIKONSUMSI }\end{array}$} & \multicolumn{7}{|c|}{ DAERAH KAJIAN } \\
\hline & $\begin{array}{l}\text { Den- } \\
\text { pasar }\end{array}$ & $\begin{array}{l}\text { Band- } \\
\text { ung }\end{array}$ & $\begin{array}{l}\text { Jabode- } \\
\text { tabek }\end{array}$ & $\begin{array}{c}\text { Sema- } \\
\text { rang }\end{array}$ & $\begin{array}{l}\text { Sura- } \\
\text { baya }\end{array}$ & Medan & Nasional \\
\hline Cair & $48 \%$ & $51 \%$ & $49 \%$ & $54 \%$ & $52 \%$ & $73 \%$ & $51 \%$ \\
\hline Serbuk & $37 \%$ & $42 \%$ & $41 \%$ & $46 \%$ & $43 \%$ & $15 \%$ & $40 \%$ \\
\hline Kapsul/pil & $15 \%$ & $8 \%$ & $10 \%$ & $0 \%$ & $5 \%$ & $12 \%$ & $9 \%$ \\
\hline
\end{tabular}

Dari sisi bentuk jamu yang dikonsumsi dan disukai konsumen, ternyata konsumsi terbesar masih berbentuk konvensional jamu cair. Persepsi kunsumen bahwa bentuk jamu adalah berbentuk cair. Selain itu, bentuk jamu cair mudah untuk dikonsumsi. Preferensi konsumen ini merupakan

\begin{tabular}{|c|c|c|c|c|c|c|c|}
\hline \multirow{2}{*}{ JENIS JAMU KEMASAN } & \multicolumn{7}{|c|}{ PERSENTASE } \\
\hline & Jabodetabek & Bandung & Semarang & Surabaya & Denpasar & Medan & Nasional \\
\hline Jamu tolak angin & $92 \%$ & $92 \%$ & $61 \%$ & $84 \%$ & $56 \%$ & $84 \%$ & $84 \%$ \\
\hline Jamu pegel linu & $79 \%$ & $80 \%$ & $52 \%$ & $88 \%$ & $54 \%$ & $64 \%$ & $75 \%$ \\
\hline Jamu kuat/sehat lelaki & $62 \%$ & $76 \%$ & $30 \%$ & $64 \%$ & $34 \%$ & $52 \%$ & $58 \%$ \\
\hline $\begin{array}{l}\text { Jamu perawatan kecantikan (lulur, spa, } \\
\text { kosmetika, anti jerawat, pelangsing, dsb) }\end{array}$ & $53 \%$ & $62 \%$ & $22 \%$ & $48 \%$ & $34 \%$ & $56 \%$ & $49 \%$ \\
\hline $\begin{array}{l}\text { Jamu pengobatan penyakit (batuk, asma, } \\
\text { kencing batu, maag, rematik, darah tinggi, } \\
\text { bersih darah, dsb) }\end{array}$ & $48 \%$ & $38 \%$ & $14 \%$ & $42 \%$ & $12 \%$ & $36 \%$ & $38 \%$ \\
\hline $\begin{array}{l}\text { Jamu perawatan kesehatan (tambah darah, } \\
\text { memperlancar asi, penenang, dsb) }\end{array}$ & $39 \%$ & $48 \%$ & $9 \%$ & $36 \%$ & $10 \%$ & $24 \%$ & $33 \%$ \\
\hline
\end{tabular}


tantangan bagi industri jamu nasional karena teknologi pembuatan dan preservasi jamu cair ini lebih sulit dan canggih Konsumen juga menyatakan bahwa mereka lebih menyukai jamu berbentuk cair, dibandingkan jamu serbuk karena dianggap lebih praktis meminumnya. Untuk jamu yang berbentuk pil/tablet, sebenarnya paling praktis, tetapi karena produk tersebut masih sedikit, prosentasenyapun juga rendah.

\section{Signifikansi dari Kepraktisan \\ Bentuk Produk Jamu Kemasan}

Dari data tabel dibawah, 79,05\% responden menganggap bahwa kepraktisan bentuk produk dari jamu adalah sesuatu yang penting dan sangat penting. Secara nasional, nilai rata rata atribut ini adalah 4,16. Artinya, responden memandang bila atribut kepraktisan bentuk produk adalah penting buat mereka. Sementara, apabila dibandingkan antara daerah satu dengan lainnya relatif tidak ada perbedaan.Untuk produk dalam bentuk kapsul/pil, lebih rendah daripada serbuk, karena jamu dalam bentuk kapsul/pil jumlahnya jauh lebih kecil dari pada jamu dalam bentuk serbuk.

\begin{tabular}{|c|c|c|c|}
\hline \multicolumn{4}{|c|}{$\begin{array}{l}\text { Tabel 3. Signifikansi Atribut Kepraktisan } \\
\text { Bentuk Produk dari Jamu kemasan }\end{array}$} \\
\hline \multicolumn{3}{|c|}{ SIGNIFIKANSI } & PERSENTASE \\
\hline \multirow{10}{*}{$\begin{array}{l}\text { Bentuk Produk } \\
\text { (Cair, bubuk, } \\
\text { tablet, kapsul, dsb) } \\
\text { Praktis }\end{array}$} & \multicolumn{2}{|c|}{ Sangat tidak penting dan tidak penting } & $5,91 \%$ \\
\hline & \multicolumn{2}{|l|}{ Netral/Ragu-ragu } & $15,04 \%$ \\
\hline & \multicolumn{2}{|c|}{ Penting dan sangat penting } & $79,05 \%$ \\
\hline & \multirow{7}{*}{ Nilai Rerata } & Jabodetabek & 4,28 \\
\hline & & Bandung & 4,14 \\
\hline & & Semarang & 4,19 \\
\hline & & Surabaya & 3,88 \\
\hline & & Denpasar & 3,92 \\
\hline & & Medan & 4,08 \\
\hline & & NASIONAL & 4,16 \\
\hline \multicolumn{4}{|c|}{$\begin{array}{l}\text { Keterangan : Makna nilai rerata } 1 \text { = sangat tidak penting; } 2=\text { tidak penting; } 3= \\
\text { netral; } 4=\text { penting; } 5=\text { sangat penting. }\end{array}$} \\
\hline \multicolumn{4}{|c|}{ Sumber: Data primer (diolah) } \\
\hline
\end{tabular}

\section{Faktor-faktor yang}

Mempengaruhi Konsumsi Jamu Kemasan

Dalam penelitian ini, faktor-faktor yang mempengaruhi konsumen meminum jamu kemasan, antara lain mutu/kualitas produk, kandungan alami, rasa, kemudahan mendapatkan produk dan harga produk.

\begin{tabular}{|c|c|c|c|c|c|c|c|c|}
\hline \multirow{2}{*}{\multicolumn{2}{|c|}{$\begin{array}{l}\text { ALASAN MENGKONSUMSI } \\
\text { JAMU KEMASAN }\end{array}$}} & \multicolumn{7}{|c|}{ PERSENTASE } \\
\hline & & Jabodetabek & Bandung & Semarang & Surabaya & Denpasar & Medan & Nasional \\
\hline \multirow{3}{*}{ Kualitas bagus } & $\begin{array}{l}\text { Tidak setuju dan } \\
\text { sangat tidak setuju }\end{array}$ & $2 \%$ & $3 \%$ & $4 \%$ & $3 \%$ & $4 \%$ & $2 \%$ & $3 \%$ \\
\hline & Netral/Ragu-ragu & $21 \%$ & $7 \%$ & $13 \%$ & $24 \%$ & $20 \%$ & $20 \%$ & $13 \%$ \\
\hline & $\begin{array}{l}\text { Setuju dan sangat } \\
\text { setuju }\end{array}$ & $76 \%$ & $90 \%$ & $83 \%$ & $73 \%$ & $76 \%$ & $68 \%$ & $80 \%$ \\
\hline \multirow{3}{*}{$\begin{array}{l}\text { Kandungan } \\
\text { alami }\end{array}$} & $\begin{array}{l}\text { Tidak setuju dan } \\
\text { sangat tidak setuju }\end{array}$ & $1 \%$ & $0 \%$ & $0 \%$ & $0 \%$ & $0 \%$ & $0 \%$ & $0 \%$ \\
\hline & Netral/Ragu-ragu & $6 \%$ & $0 \%$ & $4 \%$ & $16 \%$ & $4 \%$ & $4 \%$ & $6 \%$ \\
\hline & $\begin{array}{l}\text { Setuju dan sangat } \\
\text { setuju }\end{array}$ & $93 \%$ & $100 \%$ & $96 \%$ & $84 \%$ & $96 \%$ & $96 \%$ & $94 \%$ \\
\hline \multirow{3}{*}{ Rasa enak } & $\begin{array}{l}\text { Tidak setuju dan } \\
\text { sangat tidak setuju }\end{array}$ & $24 \%$ & $20 \%$ & $9 \%$ & $24 \%$ & $12 \%$ & $16 \%$ & $17 \%$ \\
\hline & Netral/Ragu-ragu & $35 \%$ & $4 \%$ & $78 \%$ & $44 \%$ & $36 \%$ & $56 \%$ & $42 \%$ \\
\hline & $\begin{array}{l}\text { Setuju dan sangat } \\
\text { setuju }\end{array}$ & $40 \%$ & $76 \%$ & $13 \%$ & $20 \%$ & $52 \%$ & $28 \%$ & $38 \%$ \\
\hline \multirow{3}{*}{$\begin{array}{l}\text { Produk mudah } \\
\text { didapat }\end{array}$} & $\begin{array}{l}\text { Tidak setuju dan } \\
\text { sangat tidak setuju }\end{array}$ & $11 \%$ & $0 \%$ & $4 \%$ & $8 \%$ & $4 \%$ & $24 \%$ & $9 \%$ \\
\hline & Netral/Ragu-ragu & $14 \%$ & $0 \%$ & $13 \%$ & $20 \%$ & $44 \%$ & $4 \%$ & $16 \%$ \\
\hline & $\begin{array}{l}\text { Setuju dan sangat } \\
\text { setuju }\end{array}$ & $74 \%$ & $100 \%$ & $83 \%$ & $64 \%$ & $52 \%$ & $72 \%$ & $74 \%$ \\
\hline \multirow{3}{*}{ Harga murah } & $\begin{array}{l}\text { Tidak setuju dan } \\
\text { sangat tidak setuju }\end{array}$ & $3 \%$ & $4 \%$ & $0 \%$ & $0 \%$ & $0 \%$ & $4 \%$ & $2 \%$ \\
\hline & Netral/Ragu-ragu & $10 \%$ & $0 \%$ & $4 \%$ & $8 \%$ & $8 \%$ & $4 \%$ & $6 \%$ \\
\hline & $\begin{array}{l}\text { Setuju dan sangat } \\
\text { setuju }\end{array}$ & $87 \%$ & $96 \%$ & $96 \%$ & $92 \%$ & $92 \%$ & $92 \%$ & $92 \%$ \\
\hline
\end{tabular}


Tabel 4 menunjukkan kandungan alami (94\%) menempati posisi teratas, sedangkan harga murah menduduki posisi kedua (92\%). Selanjutnya kualitas produk yang bagus (80\%) dan produk mudah di dapat (74\%).

Dilihat dari kandungan alami yang terdapat pada jamu kemasan mendapatkan nilai tertinggi, sesuai dengan tren sehat, tidak mengandung bahan kimia. Dari segi harga, jamu kemasan dinilai murah oleh konsumen. Hal ini mudah dipahami, karena bahan baku untuk pembuatan jamu kemasan hampir semua didapat dari alam Indonesia, tidak perlu impor. Dari segi kualitas, produsen jamu kemasan sudah menerapkan pengujian praproduksi, produksi hingga pasca produksi. Hal ini untuk memastikan produk mereka berkualitas. Dari segi kemudahan konsumen mendapatkan produk jamu kemasan, distribusi jamu kemasan sudah beredar di toko obat, supermarket hingga ke pedagang kaki lima. Hal ini mempermudah konsumen untuk membeli produk jamu kemasan.

Dari data tersebut, menunjukkan bahwa penilaian konsumen yang bagus (diatas 50\%) merupakan bekal yang bagus bagi produsen jamu kemasan. Rasa produk dinilai rendah (38\%) karena konsumen tidak suka dengan rasa jamu ben ${ }^{-}$ tuk serbuk.

\section{Loyalitas dan Kepuasan \\ Konsumen Terhadap Jamu Kemasan}

Loyalitas merupakan hal yang perlu diperhatikan dan dibangun oleh produsen jika produknya ingin terus dikonsumsi. Tanpa loyalitas konsumen tidak akan melakukan repeat buying dengan frekwensi sering sehingga kemapanan produk tidak akan berlangsung lama dan pada akhirnya produk menjadi tidak berkembang atau bahkan kalah bersaing dengan produk pengganti lainnya. Dalam penelitian ini, responden konsumen jamu kemasan diminta menjawab pertanyaan yang dapat menunjukkan nilai loyalitas responden atas jamu yang mereka konsumsi.

Hasil pengolahan data, pada Tabel 5 menunjukkan bahwa sebagian besar responden konsumen (85\%) merasa puas dengan produk jamu kemasan yang mereka konsumsi.

Nilai loyalitas konsumen juga semakin terlihat cukup baik dengan besarnya presentase untuk menganjurkan orang lain meminum jamu dan membiasakan diri untuk selalu minum jamu dengan persentase sebesar $62 \%$ dan 59\%. Dilihat dari loyalitas produk jamu kemasan Indonesia dibandingkan dengan produk jamu asing, sebanyak $69 \%$ responden konsumen lebih memilih produk jamu Indonesia.

\begin{tabular}{|c|c|c|c|c|c|c|c|c|}
\hline \multirow{2}{*}{\multicolumn{2}{|c|}{ KEPUASAN DAN LOYALITAS KONSUMEN }} & \multicolumn{7}{|c|}{ PERSENTASE } \\
\hline & & \multirow{2}{*}{$\begin{array}{c}\text { Jabodetabek } \\
2 \%\end{array}$} & \multirow{2}{*}{$\begin{array}{c}\text { Bandung } \\
\text { 0\% }\end{array}$} & \multirow{2}{*}{$\begin{array}{c}\text { Semarang } \\
0 \%\end{array}$} & \multirow{2}{*}{$\begin{array}{c}\text { Surabaya } \\
0 \%\end{array}$} & \multirow{2}{*}{$\begin{array}{c}\text { Denpasar } \\
0 \%\end{array}$} & \multirow{2}{*}{$\begin{array}{c}\text { Medan } \\
8 \%\end{array}$} & \multirow{2}{*}{$\begin{array}{c}\text { Nasional } \\
2 \%\end{array}$} \\
\hline \multirow{3}{*}{$\begin{array}{l}\text { Puas dengan produk } \\
\text { jamu yang di minum }\end{array}$} & $\begin{array}{l}\text { Tidak setuju dan } \\
\text { sangat tidak setuju }\end{array}$ & & & & & & & \\
\hline & Netral/Ragu-ragu & $7 \%$ & $10 \%$ & $20 \%$ & $12 \%$ & $10 \%$ & $22 \%$ & $18 \%$ \\
\hline & $\begin{array}{l}\text { Setuju dan sangat } \\
\text { setuju }\end{array}$ & $91 \%$ & $90 \%$ & $80 \%$ & $88 \%$ & $90 \%$ & $70 \%$ & $85 \%$ \\
\hline \multirow{3}{*}{$\begin{array}{l}\text { Menganjurkan } \\
\text { kepada orang lain } \\
\text { untuk minum jamu }\end{array}$} & $\begin{array}{l}\text { Tidak setuju dan } \\
\text { sangat tidak setuju }\end{array}$ & $8 \%$ & $14 \%$ & $29 \%$ & $4 \%$ & $14 \%$ & $8 \%$ & $9 \%$ \\
\hline & Netral/Ragu-ragu & $26 \%$ & $13 \%$ & $22 \%$ & $32 \%$ & $22 \%$ & $28 \%$ & $29 \%$ \\
\hline & $\begin{array}{l}\text { Setuju dan sangat } \\
\text { setuju }\end{array}$ & $66 \%$ & $73 \%$ & $49 \%$ & $64 \%$ & $64 \%$ & $64 \%$ & $62 \%$ \\
\hline \multirow{3}{*}{ Selalu minum jamu } & $\begin{array}{l}\text { Tidak setuju dan } \\
\text { sangat tidak setuju }\end{array}$ & $8 \%$ & $20 \%$ & $9 \%$ & $16 \%$ & $2 \%$ & $20 \%$ & $12 \%$ \\
\hline & Netral/Ragu-ragu & $26 \%$ & $28 \%$ & $37 \%$ & $20 \%$ & $4 \%$ & $28 \%$ & $29 \%$ \\
\hline & $\begin{array}{l}\text { Setuju dan sangat } \\
\text { setuju }\end{array}$ & $66 \%$ & $52 \%$ & $54 \%$ & $64 \%$ & $4 \%$ & $48 \%$ & $59 \%$ \\
\hline \multirow{3}{*}{$\begin{array}{l}\text { Mengutamakan } \\
\text { minum jamu } \\
\text { dibanding obat } \\
\text { farmasi (dokter) }\end{array}$} & $\begin{array}{l}\text { Tidak setuju dan } \\
\text { sangat tidak setuju }\end{array}$ & $28 \%$ & $30 \%$ & $35 \%$ & $32 \%$ & $6 \%$ & $30 \%$ & $30 \%$ \\
\hline & Netral/Ragu-ragu & $24 \%$ & $28 \%$ & $32 \%$ & $38 \%$ & $6 \%$ & $36 \%$ & $27 \%$ \\
\hline & $\begin{array}{l}\text { Setuju dan sangat } \\
\text { setuju }\end{array}$ & $48 \%$ & $42 \%$ & $33 \%$ & $30 \%$ & $38 \%$ & $44 \%$ & $43 \%$ \\
\hline \multirow{3}{*}{$\begin{array}{l}\text { Mengutamakan } \\
\text { minum jamu } \\
\text { dibanding obat jamu } \\
\text { buatan luar, seperti } \\
\text { China, Korea }\end{array}$} & $\begin{array}{l}\text { Tidak setuju dan } \\
\text { sangat tidak setuju }\end{array}$ & $10 \%$ & $12 \%$ & $9 \%$ & $24 \%$ & $16 \%$ & $16 \%$ & $15 \%$ \\
\hline & Netral/Ragu-ragu & $18 \%$ & $10 \%$ & $14 \%$ & $24 \%$ & $12 \%$ & $24 \%$ & $14 \%$ \\
\hline & $\begin{array}{l}\text { Setuju dan sangat } \\
\text { setuju }\end{array}$ & $72 \%$ & $78 \%$ & $77 \%$ & $52 \%$ & $72 \%$ & $60 \%$ & $69 \%$ \\
\hline
\end{tabular}


Namun, nilai loyalitas responden konsumen jamu dibanding obat farmasi masih relatif rendah dimana hanya $43 \%$ responden konsumen mengutamakan meminum jamu dibandingkan dengan obat modern. Dengan perkataan lain, 57\% responden konsumen jamu masih mengutamakan obat modern dalam menyembuhkan penyakit.

Rendahnya nilai rerata untuk mengutamakan meminum jamu dibandingkan obat farmasi modern merupakan cermin dasar bahwa masyarakat Indonesia, khusunya konsumen jamu, secara umum masih meragukan khasiat jamu dibanding dengan obat farmasi modern. Hal ini disebabkan karena beberapa sebab, antara lain adalah persepsi jamu untuk pengobatan penyakit klinis kurang manjur dibandingkan dengan obat farmasi

Dalam hal ini, dapat disimpulkan, walau pun mereka mengaku puas, namun belum loyal dan masih menempatkan jamu sebagai alternatif kepada obat farmasi.

Temuan ini menunjukkan bahwa industri jamu harus melakukan manajemen kepuasan dan loyalitas pelanggan yang lebih baik karena posisi mereka di benak konsumen belumlah aman. Pemerintah pun perlu membantu industri jamu dengan mengkampanyekan khasiat jamu yang tak kalah dengan obat farmasi maupun jamu impor. Dengan demikian, kepercayaan konsumen akan meningkat dan diharapkan akan berkontribusi bagi peningkatan kepuasan dan loyalitas pengguna jamu.

Kelebihan produk jamu kemasan Indonesia dibanding produk pesaing seperti produk jamu yang khasiatnya tidak dijumpai di dunia medis dan bahan baku yang alami bisa menjadi daya tarik tersendiri bagi konsumen supaya tidak beralih ke pesaing.

Untuk membuat konsumen semakin loyal, inovasi produk juga sangat diperlukan, selain itu, pengembangan varian-varian baru juga bisa membuat konsumen makin loyal.

\section{Daya Saing Jamu Kemasan \\ Indonesia di Mata Responden}

Dalam penelitian ini,akan dibandingkan antara jamu kemasan dengan obat farmasi dan obat/jamu impor untuk mengetahui seberapa besar daya saing jamu kemasan dibandingkan dengan obat farmasi dan obat/jamu impor Untuk mengujinya, dengan uji perbedaan signifikan antara produk jamu kemasan Indonesia dengan produk farmasi dan produk obat/jamu impor, digunakan uji paired $t$-test dengan tingkat signifikansi 5\%.

Daya saing jamu kemasan Indonesia akan diteliti dari beberapa sudut,antara lain :

a. Kualitas produk, b. Bentuk produk,

c. Informasi produk,

d. Kandungan alami produk

\section{Daya Saing mengenai Mutu produk}

Mutu jamu kemasan Indonesia dipersepsikan lebih tinggi dibandingkan dengan obat/jamu China/Korea/lainnya, tetapi dipersepsikan lebih rendah dibanding obat farmasi (Tabel 6).

Keunggulan mutu produk obat farmasi lebih baik dari pada jamu kemasan karena masyarakat mengetahui bahwa obat farmasi telah diuji dengan baik sebelum dipasarkan ke masyarakat. Sedangkan produk jamu kemasan, mempersepsikan pengujiannya tidak sebaik obat farmasi. Obat tradisional impor dipersepsikan lebih kurang bermutu dibandingkan dengan produk jamu kemasan karena produk obat tradisional impor yang masuk ke Indonesia beragam kualitasnya dan informasi kualitas produknyapun juga masih minimal.

\begin{tabular}{|c|c|c|c|c|c|}
\hline \multicolumn{6}{|c|}{$\begin{array}{c}\text { Tabel 6. Persepsi Responden Konsumen terhadap Posisi } \\
\text { Daya Saing Jamu Kemasan Indonesia tentang Mutu Produk }\end{array}$} \\
\hline \multirow{3}{*}{\multicolumn{2}{|c|}{ Berkualitas Tinggi }} & \multicolumn{4}{|c|}{ Nilai Rerata } \\
\hline & & $\begin{array}{c}\text { Jamu } \\
\text { kema- } \\
\text { san }\end{array}$ & $\begin{array}{c}\text { Obat } \\
\text { farmasi }\end{array}$ & \multicolumn{2}{|c|}{$\begin{array}{l}\text { Obat/ Jamu Impor } \\
\text { (China, Korea, dll) }\end{array}$} \\
\hline & & 3,95 & 4,07 & \multicolumn{2}{|r|}{3,18} \\
\hline $\begin{array}{c}\text { Analisis } \\
\text { perbedaan }\end{array}$ & $\begin{array}{l}\text { Mean } \\
\text { difference }\end{array}$ & Nilai t & df & $\begin{array}{l}\text { 2-tailed } \\
\text { Sig }\end{array}$ & Kesimpulan \\
\hline $\begin{array}{l}\text { Jamu } \\
\text { kemasan - } \\
\text { Obat farmasi }\end{array}$ &,- 114 & $-2,231$ & 45 & ,027 & $\begin{array}{l}\text { Obat farmasi } \\
\text { dipersepsi } \\
\text { secara } \\
\text { signifikan lebih } \\
\text { tinggi mutunya } \\
\text { daripada Jamu } \\
\text { kemasan. }\end{array}$ \\
\hline $\begin{array}{l}\text { Jamu } \\
\text { kemasan - } \\
\text { Obat/jamu } \\
\text { impor }\end{array}$ & ,772 & 9,283 & 45 & ,000 & $\begin{array}{l}\text { Jamu kemasan } \\
\text { dipersepsi } \\
\text { secara } \\
\text { signifikan lebih } \\
\text { tinggi mutunya } \\
\text { daripada obat/ } \\
\text { jamu import. }\end{array}$ \\
\hline
\end{tabular}

\section{Daya Saing Mengenai}

\section{Kepraktisan Bentuk Produk}

Dalam hal kepraktisan bentuk produk, jamu kemasan Indonesia lebih tinggi dibandingkan dengan obat/jamu China/Korea/lainnya, namun dipersepsikan lebih rendah dibanding obat farmasi.

Bentuk obat farmasi terbanyak adalah pil/ tablet. Bentuk ini disukai konsumen karena mudah untuk dikonsumsi. Untuk jamu kemasan, bentuk serbuk masih terbanyak, diikuti dengan bentuk cair, dan bentuk pil/tablet. Bentuk serbuk dianggap kurang praktis dikonsumsi, karena konsumen harus menyeduh dahulu. 


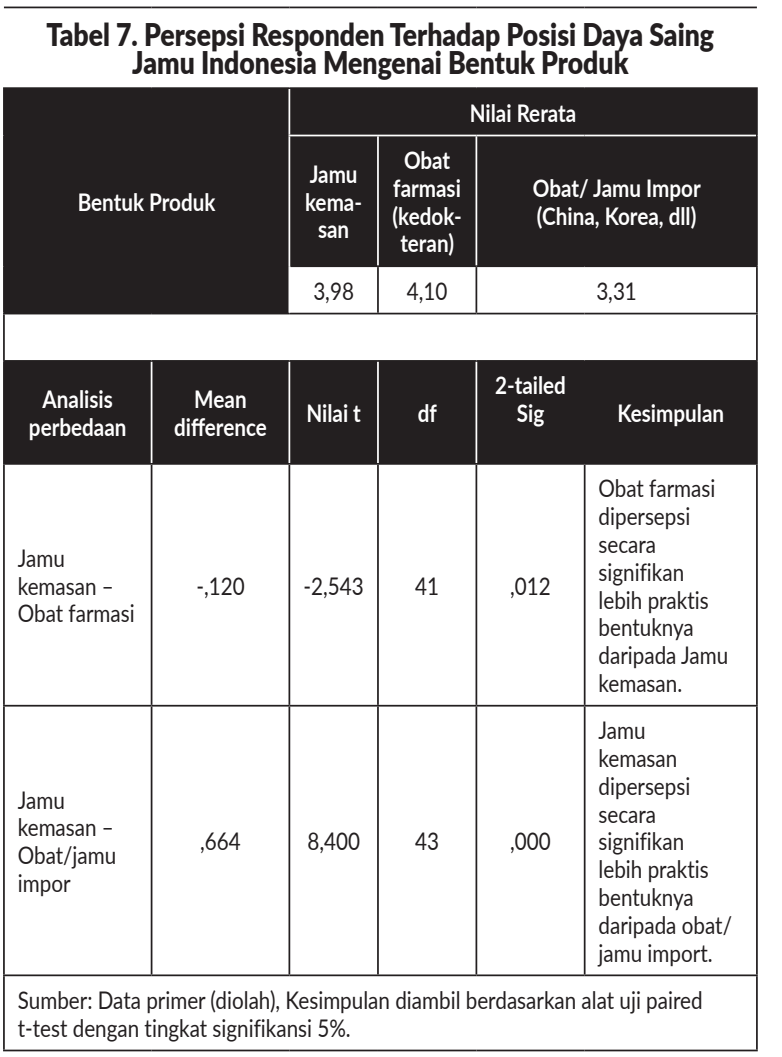

Posisi Daya Saing Jamu kemasan Indonesia di Benak Responden mengenai Penyediaan Informasi yang Jelas dalam produknya

Jamu kemasan Indonesia secara signifikan lebih tinggi dibandingkan dengan obat/jamu China/Korea/lainnya; namun dianggap secara signifikan lebih rendah dibanding obat farmasi.

Keunggulan obat farmasi adalah informasi yang ada di kemasan cukup lengkap, meliputi fungsi obat, kandungan obat, dosis pemakaian dan peringatan pemakaian obat tersebut. Produk jamu kemasan Indonesia informasinya tidak sejelas obat farmasi. Obat tradisional impor dinilai paling tidak jelas informasinya, karena informasi dalam kemasan sulit dipahami (bahasa China, Korea).

\begin{tabular}{|c|c|c|c|c|c|}
\hline \multicolumn{6}{|c|}{$\begin{array}{l}\text { Tabel 8. Daya Saing Mengenai } \\
\text { Penyediaan Informasi yang Jelas }\end{array}$} \\
\hline \multirow{3}{*}{\multicolumn{2}{|c|}{$\begin{array}{l}\text { Informasi (tentang dosis, } \\
\text { aturan pakai, efek samping) } \\
\text { yang jelas }\end{array}$}} & \multicolumn{4}{|c|}{ Nilai Rerata } \\
\hline & & $\begin{array}{c}\text { Jamu } \\
\text { kema- } \\
\text { san }\end{array}$ & $\begin{array}{l}\text { Obat } \\
\text { farmasi } \\
\text { (kedok- }\end{array}$ & \multicolumn{2}{|c|}{$\begin{array}{l}\text { Obat/ Jamu Impor } \\
\text { (China, Korea, dII) }\end{array}$} \\
\hline & & 4,01 & 4,23 & \multicolumn{2}{|r|}{3,36} \\
\hline $\begin{array}{c}\text { Analisis } \\
\text { perbedaan }\end{array}$ & $\begin{array}{c}\text { Mean } \\
\text { difference }\end{array}$ & Nilai t & df & $\begin{array}{l}\text { 2-tailed } \\
\text { Sig }\end{array}$ & Kesimpulan \\
\hline $\begin{array}{l}\text { Jamu } \\
\text { kemasan - } \\
\text { Obat farmasi }\end{array}$ &,- 217 & $-4,137$ & 243 & ,000 & $\begin{array}{l}\text { Obat farmasi } \\
\text { dipersepsi } \\
\text { secara } \\
\text { signifikan lebih } \\
\text { menyediakan } \\
\text { informasi yang } \\
\text { jelas daripada } \\
\text { Jamu kemasan. }\end{array}$ \\
\hline
\end{tabular}

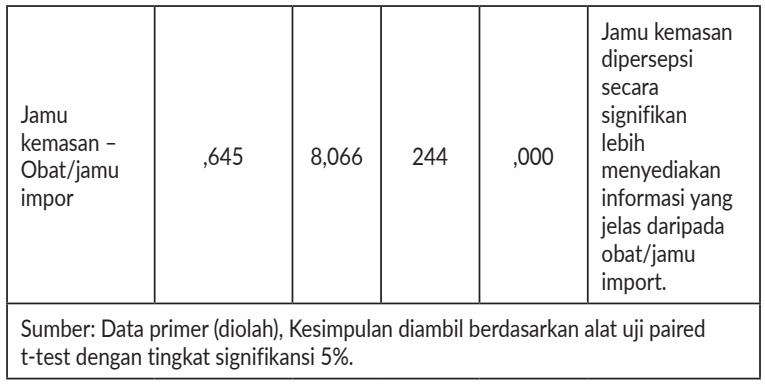

\section{Daya Saing dalam hal kandungan Alami dalam Produk}

Dalam hal kandungan yang alami, jamu kemasan Indonesia secara signifikan lebih tinggi dibandingkan dengan obat farmasi dan obat/jamu China/Korea/lainnya.

Masyarakat Indonesia mengetahui bahwa jamu adalah produk warisan leluhur yang dibuat dari bahan-bahan alami, sedangkan obat farmasi dikenal masyarakat menggunakan bahan baku kimia.

\begin{tabular}{|c|c|c|c|c|c|}
\hline \multicolumn{6}{|c|}{$\begin{array}{c}\text { Tabel 9. Persepsi Responden Terhadap Posisi Daya Saing } \\
\text { Jamu Indonesia Mengenai Kandungan Alami Produk }\end{array}$} \\
\hline \multirow{3}{*}{\multicolumn{2}{|c|}{ Kandungan Alami }} & \multicolumn{4}{|c|}{ Nilai Rerata } \\
\hline & & $\begin{array}{c}\text { Jamu } \\
\text { kema- } \\
\text { san }\end{array}$ & $\begin{array}{c}\text { Obat } \\
\text { farmasi } \\
\text { (kedok- } \\
\text { teran) }\end{array}$ & \multicolumn{2}{|c|}{$\begin{array}{l}\text { Obat/ Jamu Impor } \\
\text { (China, Korea, dll) }\end{array}$} \\
\hline & & 3,81 & 3,06 & \multicolumn{2}{|r|}{3,20} \\
\hline $\begin{array}{l}\text { Analisis } \\
\text { perbedaan }\end{array}$ & $\begin{array}{l}\text { Mean } \\
\text { difference }\end{array}$ & Nilai t & df & \multicolumn{2}{|c|}{$\begin{array}{l}\text { 2-tailed } \\
\text { Sig } \quad \text { Kesimpulan }\end{array}$} \\
\hline $\begin{array}{l}\text { Jamu } \\
\text { kemasan - } \\
\text { Obat farmasi }\end{array}$ & ,742 & 9,381 & 243 &, 000 & $\begin{array}{l}\text { Jamu kemasan } \\
\text { dipersepsi } \\
\text { secara } \\
\text { signifikan } \\
\text { lebih alami } \\
\text { kandungannya } \\
\text { daripada Obat } \\
\text { farmasi. }\end{array}$ \\
\hline $\begin{array}{l}\text { Jamu } \\
\text { kemasan - } \\
\text { Obat/jamu } \\
\text { impor }\end{array}$ &, 598 & 7,651 & 243 &, 000 & $\begin{array}{l}\text { Jamu kemasan } \\
\text { dipersepsi } \\
\text { secara } \\
\text { signifikan } \\
\text { lebih alami } \\
\text { kandungannya } \\
\text { daripada obat/ } \\
\text { jamu import. }\end{array}$ \\
\hline \multicolumn{6}{|c|}{$\begin{array}{l}\text { Sumber: Data primer (diolah),kesimpulan diambil berdasarkan alat uji paired } \\
\text { t-test dengan tingkat signifikansi } 5 \% \text {. }\end{array}$} \\
\hline
\end{tabular}

\section{SIMPULAN}

Kesimpulan

Berdasarkan hasil penelitian dan pembahasan yang telah dilakukan oleh penulis tentang "Strategi Pengembangan Jamu Kemasan di Indonesia", maka penulis dapat menarik kesimpulan sebagai berikut:

1. Jenis jamu kemasan yang dikonsumsi oleh konsumen adalah produk jamu kemasan yang khasiatnya tidak ada di dalam produk 
obat medis, seperti Jamu Tolak Angin, Jamu Pegel linu dan lainnya. Jamu kemasan untuk perawatan kesehatan dan kecantikan juga cukup laku di pasaran.

2. Bentuk Jamu kemasan yang disukai konsumen adalah berbentuk cair dan pil/tablet.

3. Keunggulan jamu kemasan pada kandungan alami di produk jamu kemasan, kualitas produk yang bagus, kemudahan mendapatkan produk dan harga yang terjangkau.

a. Daya saing produk jamu kemasan dibandingkan dengan produk obat medis kurang baik, terutama dalam hal kualitas produk jamu kemasan, bentuk produk dan kejelasan informasi dalam produk. Hanya dalam hal kandungan alami,jamu kemasan lebih unggul dari pada obat medis.

b. Daya saing produk jamu kemasan dibandingkan dengan jamu produk impor lebih baik,terutama dalam hal kualitas produk, bentuk produk, kejelasan informasi dan kandungan alami pada produk

4. Masalah masih belum tingginya loyalitas pengguna terhadap jamu. Sebagian besar pengguna masih menempatkan jamu sebagai alternatif kepada obat farmasi

\section{Saran}

1. Produsen jamu kemasan memfokuskan produknya pada jenis jamu yang tidak terdapat di produk obat medis. Hal ini bisa dilakukan dengan melakukan riset di masyarakat tentang penyakit yang diderita oleh masyarakat, tetapi belum ada obat medisnya. Selain itu juga produk penjaga kesehatan dan perawatan tubuh juga potensial untuk diproduksi.

2. Bentuk produk difokuskan ke bentuk yang praktis, seperti bentuk cair, pil/tablet.

Dengan perkembangan jaman saat ini, semua hal ingin praktis,Jamu kemasan berbentuk cair sudah cukup banyak diproduksi dan disukai konsumen, sedangkan bentuk pil/tablet masih belum banyak diproduksi.

3. Informasi pada produk jamu kemasan diperjelas, seperti khasiat, komposisi jamu dan aturan pakai. Masyarakat menginginkan lebih detail mengenai informasi yang terdapat pada produk jamu kemasan

\section{DAFTAR PUSTAKA}

Aaker, D.A. 1995. Building Strong Brands. New York: The Free Press.

Aaker, D.A.1989. "Managing Assets and Skills: The Key to a Sustainable Competitive Advantage," California Management Revie, Winter, pp.91- 106.

Aaker, D.A.1991. Managing Brand Equity: Capi- talizing on the Value of a Brand Name. New York: The Free Press.

Assael, Henry, (1987), Consumer Behavior and Marketing Action, Third Edition, Boston: PWS-Kent Publishing Company.

Baker, Michael J. 2003. The Marketing Book. Oxford: Butterworth Heinemann. Bandung.

Baron, R. A. and Byrne, D. 1997. Social Psychology, $8^{\text {th }}$ edition. Boston, MA: Allyn and Bacon.

Eagly and Chaiken. 1993. The Psychology of Attitudes, Fort Worth, TX: Harcourt Brace Jovanovich

Engel, J.F., Blackwell, R.D. and Miniard, P.W. 1994. Consumer Behavior, $6^{\text {th }}$ ed., The Dryden Press, Chicago, IL.

Fraering, J.M. 2002. "Community, Fortutide, Satisfaction and Loyalty: Tests of Oliver's Proposed Frameworks", Dissertation, University of Texas-Pan American.

Hair, J.F. Jr, Anderson, R.E., Tatham, R.L. and Black, W.C. 1998. Multivariate Data Analysis, $5^{\text {th }}$ ed., Prentice-Hall, Englewood Cliffs, NJ.

Istijanto, MM, M.Comm. 2009. Aplikasi Praktis Riset Pemasaran. Gramedia Pustaka Utama. Jakarta.

Kotler, Philip. 2002. Manajemen Pemasaran: Jilid 1. Edisi Milenium. Jakarta. Prehallindo.

Kotler, Philip, "Manajemen Pemasaran",Edisi 12 jilid 1, Penerbit PT Indeks Kelompok Gramedia, Jakarta 2009

Kuncoro, Mudrajad, "Metode Riset Untuk Bisnis \& Ekonomi,Bagaimana Meneliti \& Menulis Tesis?" Penerbit Erlangga,Jakarta 2003

Schiffman, Leon G. \& Leslie L. Kanuk. 2000. Consumer Behavior: Fifth Edition. New Jersey. Prentice-Hall Inc.

Swastha, Basu \& Handoko, Hani. 2011. Manajemen Pemasaran-Analisis Perilaku Konsumen. Yogyakarta. BPFE.

---. 2008. Laporan Tahunan. Balai Besar Pengawasan Obat dan Makanan. 